A207 周囲組織を考慮した開放耳管のモデル化 一有限要素モデルによる解析一

\title{
Modeling of the patulous Eustachian tube with surrounding tissue: FEM analysis
}

\author{
○学 井上 博文 (電通大) \\ 正 小池 卓二（電通大） \\ 正 本間 恭二 (電通大) \\ 正 村上 小百合 (電通大)
}

Hirofumi INOUE, The University of Electro-Communications, Chofugaoka1-5-1, Chofu, Tokyo

Takuji KOIKE, The University of Electro-Communications

Kyoji HOMMA, The University of Electro-Communications

Sayuri MURAKAMI, The University of Electro-Communications

Key Words: Eustachian Tube, Sniff, Patulaus Eustachian Tube Syndrome, Finite Element Method, Coupling Analysis

\section{1. 緒言}

耳管（Eustachian tube，Fig. 1) は，鼓室（tympanic cavity） と鼻咽頭（nasopharynx）を結ぶ管状構造物で, 鼓室内の圧調 整に不可欠な器官である.耳管は周囲を骨や軟骨，筇肉や脂 肪組織に囲まれており，正常な状態では閉鎖している。しか し，耳管開放症（patulous Eustachian tube syndrome）になる と, 耳管は常時開放した状態になり, 耳閉塞感, 自声強調等 の症状が引き起こされる(1). その際, 医師が行う処置として, 耳管ピンを挿入し，開放した耳管を閉鎖させる方法がある. また，患者が鼻すすりを行うと，耳管が閉鎖され，症状が和 らぐことがある.しかし，耳管の挙動は，直接観察が困難な ため,その詳細は明らかになっていない。

本研究では, ヒトの実際の形状に近い耳管及び周囲組織と, 簡略化した鼓室と鼓膜の3次元モデルを作成し, 鼻すすりに よる耳管全体の変形挙動や圧力変化を,耳管とその内部を流 れる空気との連成を考慮して, 有限要素法 (finite element method, FEM）を用いて解析を行った.

\section{2. 解析方法}

Fig. 2 に, 本研究で構築した鼓室及び, 開放状態のヒト耳 管とその周囲組織の3次元FEMモデルを示す.モデル化を行っ た部位は，耳管，Ostmann's 脂肪組織（Ostmann's fat tissure）, 耳管軟骨 (cartilage), 口蓋帆張筋 (tensor veli palatine muscle), 口蓋帆挙筋 (levator veli palatine muscle), 鼓室 (tympanic cavity），鼓膜（tympanic membrane）である. 本モデルの各部 の形状・寸法は, ヒト側頭骨の標本断面写真をトレースした もの ${ }^{(3)}$, 耳管のコンピュータによる立体的再構築像 ${ }^{(3)}$, ヒト の解剖所見 (4) を元に決定した。また; 鼓室と鼓膜に関して は，それぞれ直方体と円板状の単純な形状でのモデル化を 行った.

耳管各部の物性值は不明なため, 耳管軟骨は耳珠軟骨の值 （ヤング率 $4 \mathrm{MPa}$ ，密度 $1100 \mathrm{~kg} / \mathrm{m}^{3}$ ，ポアソン比 0.3 ）を用い た。また，耳管軟骨には，エラスチン (elastin) と呼ばれる弾 性繊維状のタンパク質が存在していると報告 ${ }^{(3)}$ があるため, 本モデルでは, Fig. 2 に示すように, 耳管軟骨の一部にエラ スチンからなる部位を設け, ヤング率を $0.4 \mathrm{MPa}$ とすること で表現した.耳管には主成分をコラーゲン繊維としている細 静脈の值 (ヤング率 $0.1 \mathrm{MPa}$, 密度 $1000 \mathrm{~kg} / \mathrm{m}^{3}$, ポアソン比

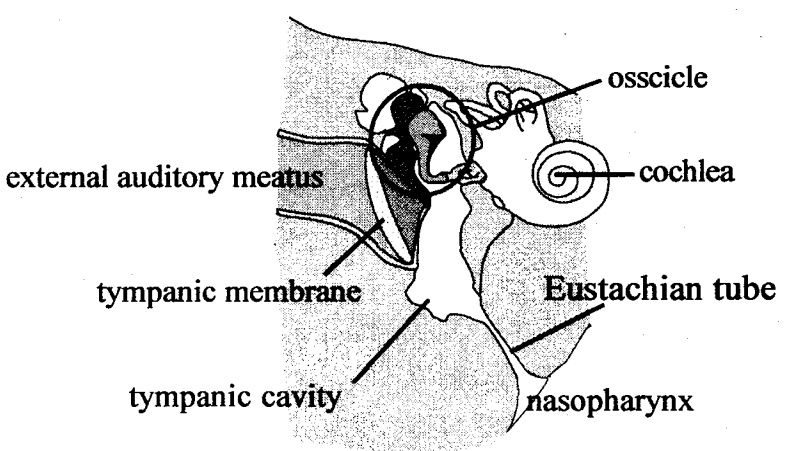

Fig. 1 Structure of the human middle ear.

tympanic cavity

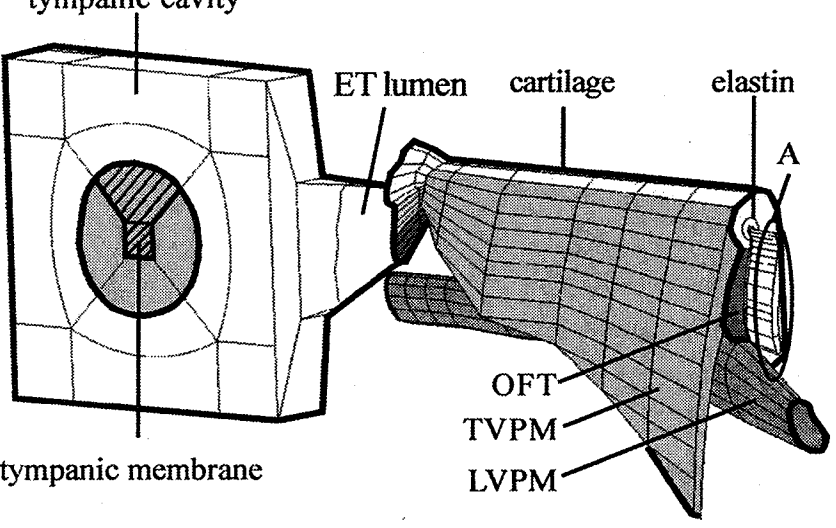

Fig. 2 FEM model of the ET with surrounding tissue.

Gray lines indicate totally fixed area. OFT, Ostmann's fat tissure; LVPM, levator veli palatine muscle; TVPM, tensor veli palatine muscle. A, Temporary outflow part of fluid.

0.49）を使用した。 また, 脂肪組織のヤング率には, 一般成 人で計測された值 $(0.5 \mathrm{MPa})$ を使用し, 筋肉のヤング率には カエル半腱筋の生体外引張試験において計測された值を参考 に $0.3 \mathrm{MPa}$ とした. エラスチンと脂肪組織, 及び筋肉の密 度は不明なため,ここでは $1000 \mathrm{~kg} / \mathrm{m}^{3}$ とした. 減衰につい ては, Rayleigh 減衰を仮定し, その係数を $\alpha=19, \beta=6.5 \times$ $10^{-3}$ とした.

本モデルでは, Fig.2 のAに示すように, 耳管咽頭口 (pharyngeal orifice) に流体部である耳管内腔（ET lumen）を延長し た仮想の流出部を作成し, 耳管咽頭口における不自然な空気

日本機械学会〔No. 06-46〕第17回バイオフロンティア講演会講演論文集（’06.11.11～12 上田市） 
の流れを改善した. 鼻すすりの際に, 耳管咽頭口で計測され た圧力と時間の関係を参考に, 次式 $\mathrm{P}_{\mathrm{n}}=9200 \sin \left(2.5 \pi \mathrm{t}^{-} \pi /\right.$ 2)-9200 [Pa] に従い，時間 $\mathrm{t}$ により減少する陰圧を，仮想の 流出部に負荷することで，鼻すすりの状態を表現した.拘束 条件は, 形態学上の見知から変形が小さいと考えられる, 鼓 室口側の断面, 耳管開口部である耳管咽頭口, 耳管と耳管軟 骨及び, 鼓室が骨に直接接触している部分を完全に固定した (Fig. 2 の太線で囲まれた部分).

上記の条件を用いて, 本モデルで耳管とその内部を流れる 空気との連成を考慮し, 時間幅を $0.01 \mathrm{~s}$ として, 耳管が接 するまでの解析を行った. なお, 解析には汎用連成解析ソフ トである CFD-ACE+V2006（ESI CFD Inc.）を使用した.

\section{3. 解析結果}

\section{1. 耳管の変形挙動}

Fig. 3(a) は, 耳管咽頭口における耳管内腔断面に陰圧が負 荷された場合の耳管の変形状態の時間変化を,耳管側面から 見た図である.なお,耳管壁面の変形を見やすくするため,脂 肪組織, 筋肉は省略して図示してある.これから, 耳管の変 形は, A-A で示した部位にある耳管最狭部 (内腔幅 $447 \mu \mathrm{m}$ ) の部位から始まっていることがわかる.これは脂肪組織や筋 肉をモデル化せず, 構造部のみ考慮し, 連成解析を行わずに 求めた結果(2)と同樣であった.

Fig. 3(b) は, 耳管の咽頭口に圧力を加える前の開放時の耳 管最狭部 (narrowest portion) の断面形状を，(c) は耳管の閉鎖 が始まった時の耳管最狭部の断面形状を示している.閉鎖が 始まった部位は, 内腔上部 (Fig. 3(c) の破線で囲まれた部位) で,これは耳管の換気機能を担う部位が, 内腔上部であると いう報告(3)からも妥当であるといえる.

耳管の周囲組織を考慮していない耳管モデル(2)では, 閉鎖 の始まった部位は, 剛性の高い耳管軟骨に囲まれている内腔 上部ではなく, 内腔下部であった.このように違いが生じた 理由は, 本モデルでは, 耳管に付着している周囲組織を考慮 したことで, 耳管の内腔下部では脂肪組織と筋肉の質量や剛 性の影響のため,内腔下部の閉鎖が抑えられたためだと考え られる。

\section{2. 耳管の閉鎖に対する脂肪組織の用性による影警}

脂肪組織の剛性が, 耳管内腔の閉鎖におよぼす影響を調べ るため, 脂肪組織のヤング率を基準值 $(500 \mathrm{kPa})$ の $1 / 10$ とし て解析を行った。

耳管内腔が最初に接した部位は, 脂肪組織のヤング率を基 準値とした場合と同じく耳管最狭部であったが, 接するまで に要した時間は基準值の場合, 鼻すすり開始後 $0.16 \mathrm{~s}$ (咽頭 口圧 -6.4 kPa) であるのに対して,ヤング率を低下させた場合 では, 鼻すすり開始後 $0.12 \mathrm{~s}$ (咽頭口圧 $-3.8 \mathrm{kPa}$ ) となり, 耳 管内腔の閉鎖が早まった. Fig. 4 は, 耳管最狭部の耳管とそ の周囲組織の断面形状の, 鼻すすり開始後 $0.12 \mathrm{~s}$ (咽頭口圧 $-3.8 \mathrm{kPa}$ ) での図中の X方向への変形量を基準值の場合 (Fig. 4(a)) と, ヤング率を低下させた場合 (Fig. 4(b)) について示し たものである. 基準値の場合は, 変形はほとんど生じていな い.ヤング率を低下させた場合は, 耳管内腔の下部とその周 囲組織に変形が見られる.このことから, 耳管内腔の接触に 要する圧力には, 脂肪組織の剛性による影響が大きいと言え る. (a)

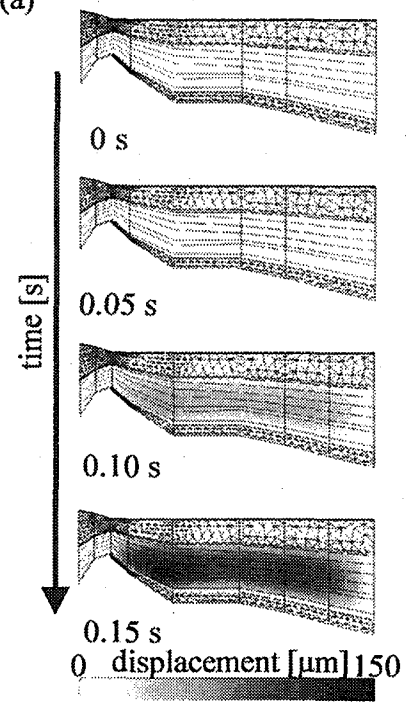

(c)

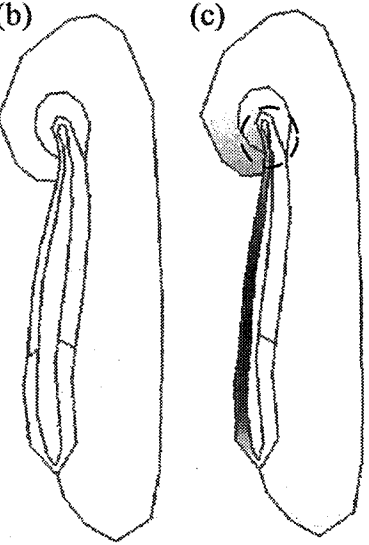

A-A section

(narrowest portion)

Fig. 3 Deformation caused by applying the pressure to the pharyngeal orifice. (a)time domain analysis, (b)before applying the pressure, (c)after 0.15 seconds.
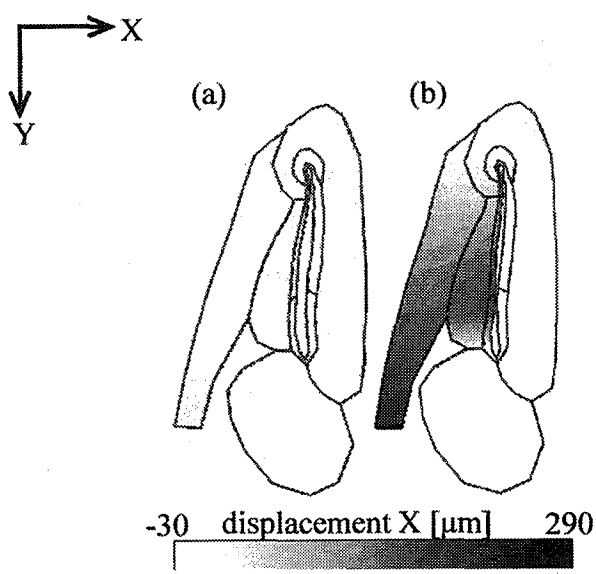

Fig. 4 Effect of the Young's modulus of Ostmann's fat tissue on the deformation of the ET at the narrowest portion at 0.11 seconds after sniff. (a) $500 \mathrm{kPa}$, (b)50 kPa.

\section{4. 結言}

周囲組織を考慮した開放耳管モデルを用いて,鼻すすりの 際の解析を行うことにより, 以下の所見を得た.

(1) 鼻すすり時における耳管の閉鎖は, 耳管最狭部からはじま る.

(2) 耳管内腔の接触に要する圧力には, 脂肪組織の剛性による 影響が大きい。

\section{参考文献}

(1) Flisberg,K., Ingelstedt,s., Middle-ear mechanics in patulous tube case, Acto Otolaryng. 263, 18-22(1970)

(2) 五味田愼一, 咽頭圧変化による開放耳管の変形挙動解析, 電気通信大学, (2005)

(3) 山藤勇, 臨床医のための側頭骨・耳管アトラス, 金原出版, (1998)

(4) Bruce Proctor, MD, Royal Oak., Mich., Anatomy of the Eustachian tube, Arch Otolaryngol. 97, 2-8(1973) 